\title{
HUBUNGAN PRODUKTIVITAS PRIMER FITOPLANKTON DENGAN KETERSEDIAAN UNSUR HARA DAN INTENSITAS CAHAYA DI PERAIRAN TELUK KENDARI SULAWESI TENGGARA
}

\author{
(Phytoplankton primary productivity relationship to the availability of nutrient element and light \\ intensity in the waters of Kendari Bay, Southeast Sulawesi) \\ Nur Irawati*, Enan M. Adiwilaga** dan Niken T.M. Prawtiwi** \\ *) Jurusan Perikanan, FPIK-Unhalu \\ **) Departemen Manajemen Sumberdaya Perairan, FPIK-IPB
}

\begin{abstract}
ABSTRAK
Penelitian ini merupakan kajian tentang hubungan produktivitas primer fitoplankton dengan ketersediaan unsur hara dan intensitas cahaya di perairan Teluk Kendari. Penelitian ini dilaksanakan di Perairan Teluk Kendari pada bulan April - Juni 2009 dengan menempatkan 3 stasiun penelitian. Tujuan penelitian adalah mengkaji hubungan antara produktivitas primer fitoplankton (NPP) dengan ketersediaan unsur hara dan intensitas cahaya (ICM) di perairan Teluk Kendari. Hasil penelitian menunjukkan bahwa nilai produktivitas primer selama penelitian pada perairan Teluk Kendari yaitu pada stasiun luar teluk berkisar $16,99-26,37 \mathrm{mgC} / \mathrm{m}^{3} / 4 \mathrm{jam}$, pada stasiun tengah teluk 21,09-31,25 $\mathrm{mgC} / \mathrm{m}^{3} / 4 \mathrm{jam}$, dan $11,13-24,61 \mathrm{mgC} / \mathrm{m}^{3} / 4 \mathrm{jam}$ pada stasiun dalam teluk. Hubungan produktivitas primer dengan unsur hara dan ICM memperlihatkan keeratan hubungan yang kuat pada ketiga stasiun penelitian sedang produktivitas primer dengan unsur hara dan ICM menunjukkan pola yang hampir sama pada ketiga stasiun penelitian. Pada stasiun luar teluk, unsur hara amonia dan nitrat bersama ICM menjadi faktor yang memberikan pengaruh nyata terhadap tinggi rendahnya nilai NPP, sedang pada stasiun tengah dan dalam teluk, unsur hara nitrat dan ICM memberikan pengaruh yang nyata terhadap tinggi dan rendahnya nilai NPP di perairan Teluk Kendari.
\end{abstract}

\begin{abstract}
The sudy on the Phytoplankton primary productivity relationship to the availability of nutrient element and light intensity in the waters of Kendari Bay was conducted on April-June 2009 at three sites. The purpose of this research was to examine the relationship between primary productivity of phytoplankton with nutrient availability and light intensity in the waters of the Bay of Kendari. Based on the data description and laboratory analysis, net primary productivity values during the survey period varied from 11.13 to $31.25 \mathrm{mgCl} \mathrm{m}^{3} / 4$ hour with ranges of average value of NPP from 20.0 to $24.46 \mathrm{mgC} / \mathrm{m}^{3} / 4$ hour. Sampling station located at the middle of the bay had the highest NPP value followed by sampling station positioned at the mouth of the bay and the lowest value was found at sampling station located near the river mouth of the upper part of the bay. Relationship between primary productivity and light intensity depicted a strong correlation at the three sampling stations. Relationship of primary productivity to nutrient and light intensity showed that the relationship were high in all three stations. Similar pattern of relationship were shown among the three stations. At the station located out of the Kendari Bay, nutrient element $N$ (both ammonia and nitrate) and light intensity were the main factors that signifacantly influence the level of NPP value, while station located in the middle and inside the bay, results reveal that nitrate and light intensity had significat influnce on the level of NPP values.
\end{abstract}

Key words: primary productivity of phytoplankton, nutrient elements, light intensity 


\section{PENDAHULUAN}

$\mathrm{T}$ leluk Kendari sebagai salah satu wilayah pesisir memiliki potensi sumberdaya perairan dan fungsi pendukung kehidupan yang sangat penting. Sebagai sumberdaya perairan, Teluk Kendari merupakan habitat bagi sejumlah organisme yang hidup di dalamnya, antara lain ikan, organisme makrofita dan mikrofita, organisme dasar (bentos), hutan mangrove, maupun padang lamun. Berbagai kegiatan baik jasa kelautan seperti pelabuhan untuk pelayaran dan perikanan, maupun kegiatan-kegiatan lain di sekitar pantai seperti permukiman, perindustrian, pertambakan, dan sebagainya merupakan bagian dari faktor pendukung kehidupan manusia.

Kegiatan penduduk yang meningkat di sekitar teluk umumnya akan memberikan dampak pada kualitas maupun produktivitas perairan di teluk karena limbah dari semua kegiatan tersebut, baik langsung ataupun tidak langsung, akan masuk ke perairan teluk. Peningkatan unsur hara yang berasal dari aktivitas manusia dapat mengakibatkan peningkatan produktivitas primer perairan serta akan mempengaruhi kelimpahan dan struktur komunitas di perairan Teluk Kendari. Dalam kondisi unsur hara yang tinggi, pertumbuhan jenis-jenis fitoplankton dapat berlangsung dengan sangat cepat, sehingga diduga dapat memicu terjadi blooming dari fitoplankton yang dominan di perairan tersebut.

Tingginya tingkat kekeruhan merupakan masalah bagi perairan Teluk Kendari. Kekeruhan yang terjadi disebabkan oleh beban masukan, baik yang berasal dari hasil aktivitas manusia (unsur hara dan polutan) maupun dari berbagai sistem aliran sungai (sedimen), serta fitoplankton. Hal ini akan menurunkan tingkat kecerahan perairan. Tingkat kecerahan perairan mempengaruhi penetrasi cahaya yang masuk ke dalam kolom perairan. Kekeruhan yang tinggi akan mempengaruhi penetrasi cahaya ke dalam kolom perairan, sehingga akan menurunkan produktivitas primer fitoplankton di perairan. Melihat fenomena-fenomena tersebut, perlu diadakan penelitian mengenai hubungan produktivitas primer fitoplankton dengan ketersediaan unsur hara pada berbagai tingkat kecerahan di perairan Teluk Kendari.

Penelitian ini bertujuan untuk menentukan nilai produktivitas primer di perairan Teluk Kendari dan mengkaji hubungan antara produktivitas primer fitoplankton dengan ketersediaan unsur hara dan intensitas cahaya di perairan Teluk Kendari. Hasil penelitian ini diharapkan dapat memberikan informasi mengenai kondisi perairan Teluk Kendari dan dapat dimanfaatkan sebagai salah satu sumber rujukan dalam pengelolaan sumberdaya perairan Teluk Kendari.

\section{BAHAN DAN METODE}

Penelitian ini dilaksanakan di perairan Teluk Kendari yang secara geografis terletak pada $3^{\circ} 57^{\prime} 50^{\prime \prime}-3^{\circ} 5^{\prime} 30^{\prime \prime}$ LS dan $122^{\circ} 31^{\prime} 50^{\prime \prime}$ $122^{\circ} 36^{\prime} 30^{\prime \prime}$ BT dengan luas $\pm 18,75 \mathrm{~km}^{2}$ dan panjang garis pantai $\pm 35,85 \mathrm{~km}$. Penelitian ini dilaksanakan selama kurang lebih dua bulan yang dimulai pada bulan April-Juni 2008 (musim kemarau).

Lokasi sampling secara horisontal dibagi menjadi tiga stasiun, yaitu stasiun A pada bagian luar teluk, stasiun B di tengah teluk, dan stasiun C pada bagian dalam teluk. Setiap stasiun memiliki dua titik sampling (substasiun). Secara vertikal, setiap stasiun/substasiun dibagi atas empat kedalaman berdasarkan intensitas cahaya di kolom perairan, yaitu kedalaman dengan intensitas cahaya $100 \%, 50 \%, 25 \%$, dan $1 \%$ dari intensitas cahaya permukaan perairan. Posisi stasiun selengkapnya ditampilkan dalam Gambar 1.

Parameter yang diukur meliputi parameter fisika, kimia dan biologi, yang dibagi menjadi parameter utama dan penunjang. Parameter penunjang meliputi suhu, salinitas, $\mathrm{pH}$, kecepatan arus, kecerahan,TSS dan kekeruhan. Parameter utama terdiri atas amonia, nitrat, nitrit, ortofosfat, silikat, intensitas cahaya (ICM), dan produktivitas primer fitoplankton.

\section{Produktivitas Primer Fitoplankton}

Pengukuran produktivitas primer dilakukan dengan metode oksigen botol terangbotol gelap. Prinsip kerja metode ini adalah mengukur perubahan kandungan oksigen dalam botol terang dan botol gelap yang berisi sampel air setelah diinkubasi pada kedalaman perairan. Waktu inkubasi dilakukan pada pukul 10.00 14.00 WITA. Pada masing-masing stasiun dan kedalaman digunakan 3 botol oksigen berukuran $250 \mathrm{ml}$, dengan perincian 1 botol terang, 1 botol gelap, dan 1 botol awal. Botol gelap dimodifikasi dengan jalan dilapisi plastik hitam, 
sehingga tidak tembus cahaya. Pengambilan contoh air dilakukan pada setiap stasiun dan kedalaman dengan menggunakan Van dorn water sampler, kemudian dimasukkan ke dalam botol- botol inkubasi dan botol awal. Kemudian, botol awal diukur sebagai oksigen terlarut awal dan botol lainnya diinkubasi.

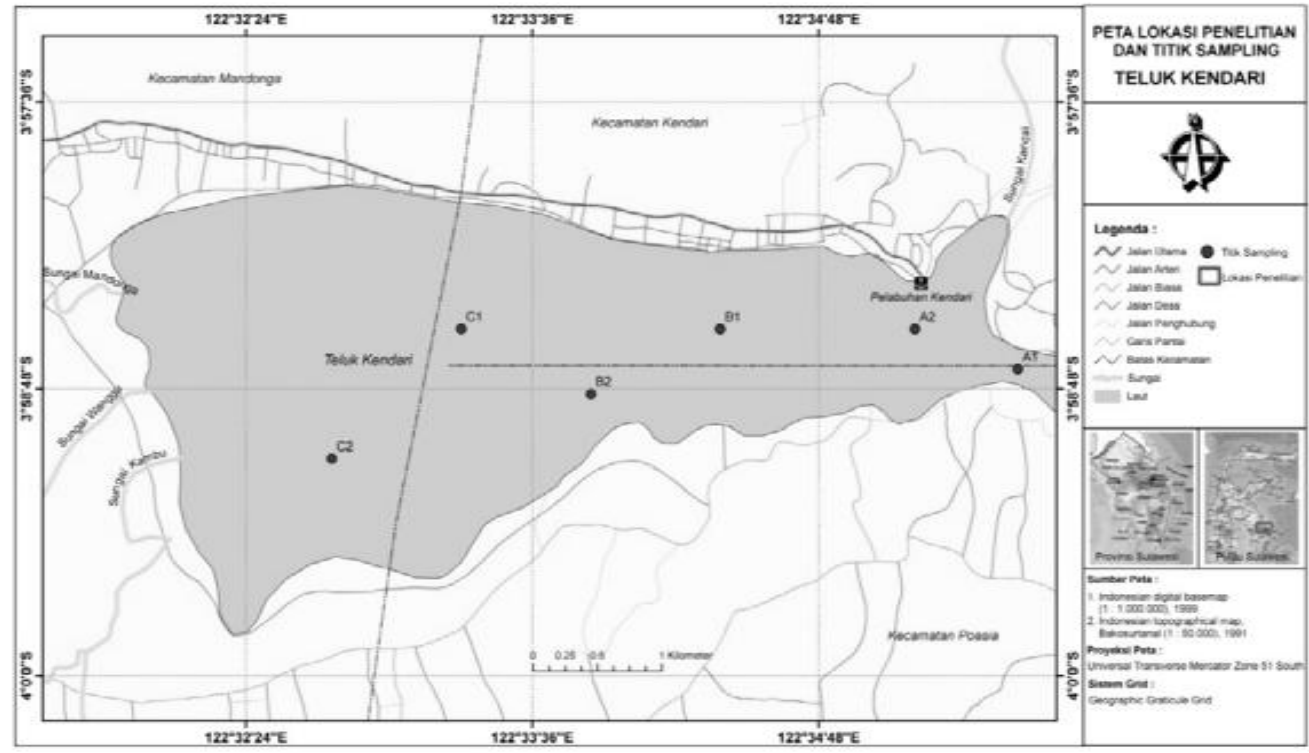

Gambar 1. Denah lokasi penelitian.

yaitu

Perhitungan produktivitas primer fitoplankton dilakukan menurut Umaly dan Cuvin (1988),

$$
\text { Fotosintesis Bersih }\left(\mathrm{mgC} / \mathrm{m}^{3} / \mathrm{jam}\right)=\frac{\left(O_{2} B T\right)-\left(O_{2} B A\right) \times 1000 \times 0,375}{(P Q) \times(t)}
$$

Keterangan : $\mathrm{O}_{2} \mathrm{BT}=$ Oksigen terlarut botol terang $(\mathrm{mg} / \mathrm{L}), \mathrm{O}_{2} \mathrm{BG}=$ Oksigen terlarut botol gelap $(\mathrm{mg} / \mathrm{L}), \mathrm{O}_{2} \mathrm{BA}=$ Oksigen terlarut botol awal $(\mathrm{mg} / \mathrm{L}), 1000=$ Konversi liter menjadi $\mathrm{m}^{3}$, $\mathrm{PQ}=$ Photosintetic Quotient $:$ 1,2 dengan asumsi hasil metabolisme dari fitoplankton,

Lama inkubasi (jam), $0,375=$ Koefisien konversi oksigen menjadi karbon (12/32). Photosintetic Quotient adalah perbandingan $\mathrm{O}_{2}$ terlarut yang dihasilkan dengan $\mathrm{CO}_{2}$ yang digunakan melalui proses fotosintesis. Menurut Parson et.al (1984) dan Oviatt et al. (1986) diacu dalam Oviat et al. (2002), nilai PQ berkisar 1,1 1,3 untuk organisme yang memiliki klorofil. Nilai 1,2 diperoleh dengan asumsi bahwa hasil metabolisme sebagian besar didominasi oleh fitoplankton.

\section{Analisis Unsur Hara}

Sampel air laut dimasukkan ke dalam botol sampel berkapasitas $250 \mathrm{ml}$ untuk keperluan analisis amonia, nitrat, nitrit, ortofosfat dan silikat. Botol sampel dimasukkan ke dalam kotak pendingin sebelum dianalisis. Sebelum dianalisis lanjutan di laboratorium, terlebih dahulu dilakukan filtrasi terhadap air sampel dengan membran filter berdiameter $47 \mathrm{~mm}$ yang berporositas $1,2 \mathrm{~m}$. Selanjutnya analisis kandungan unsur-unsur hara tersebut dilakukan mengacu pada APHA (2005).

\section{Intensitas Cahaya}

Pengukuran intensitas cahaya dilakukan dengan menggunakan luxmeter tipe Lutron LX101 (Digital Luxmeter Takemura Elektric Work. Ltd). Pengukuran intensitas cahaya dilakukan setiap 10 menit sekali yang dimulai pada jam 06.00 - 17.30 WITA di wilayah daratan tempat pengambilan sampel. Prinsip kerja alat ini adalah menangkap energi cahaya melalui sensor berupa photoelectric cell dan merubahnya menjadi sinyal yang terbaca melalui lux selector. Untuk memperoleh nilai intensitas cahaya yang berada pada lapisan permukaan perairan, nilai intensitas cahaya yang diperoleh dari pengukuran di daratan dikurangi $10 \%$ dengan asumsi intensitas cahaya mengalami refleksi oleh permukaan air laut (Kirk 1994; Damar 2003). Sedang untuk 
menilai distribusi intensitas cahaya matahari pada setiap kedalaman kolom air ditentukan menurut Hukum Beer-Lambert (Cole 1988), yaitu

$$
I_{z}=I_{0} e^{-k z}
$$

Keterangan $: \mathrm{I}_{\mathrm{z}}=$ Intensitas cahaya pada suatu kedalaman $\mathrm{z}, \mathrm{I}_{0}=$ Intensitas cahaya pada permukaan perairan, $\mathrm{e}=$ Bilangan dasar $\operatorname{logaritma}(2,70), \mathrm{k}=$ Koefisien peredupan, $\mathrm{z}=$ Kedalaman. Koefisien peredupan pada kolom perairan dihitung dengan pembacaan kedalaman keping secchi disk (Sd (m)) dengan menggunakan persamaan empiris $k=0,191+1,242 / S_{d}\left(r^{2}=0,853\right)$ (Tillman et al. 2000).

Analisis Data

Analisis sidik ragam (ANOVA) digunakan untuk mengetahui apakah terdapat perbedaan distribusi terhadap produktivitas primer fitoplankton baik secara horisontal maupun secara vertikal dan distribusi unsur hara pada masing-masing stasiun penelitian. Analisis regresi linier berganda dilakukan untuk mengetahui hubungan antara unsur hara dan intensitas cahaya perairan terhadap produktivitas primer fitoplankton pada setiap stasiun (Mattjik dan Sumertajaya 2000). Untuk mengetahui hubungan antara intensitas cahaya (ICM) dengan produktivitas primer pada setiap stasiun dilakukan analisis regresi non linier dengan pola kuadratik. Uji analisis sidik ragam (Anova) dan regresi berganda dilakukan menggunakan program SPSS versi 13.0, dan Ms-excel.

\section{HASIL}

\section{Produktivitas Primer Fitoplankton}

Nilai produktivitas primer bersih (NPP) yang diperoleh selama penelitian berkisar 10,16$35,94 \mathrm{mgC} / \mathrm{m}^{3} / 4$ jam pada stasiun A, 11,09-
$44,54 \mathrm{mgC} / \mathrm{m}^{3} / 4$ jam pada stasiun $\mathrm{B}$, dan 13,33 $36,77 \mathrm{mgC} / \mathrm{m}^{3} / 4$ jam pada stasiun $\mathrm{C}$, dengan ratarata nilai NPP antara stasiun selama penelitian berturut-turut untuk stasiun $\mathrm{A}, \mathrm{B}$, dan $\mathrm{C}$ yaitu $20,41 \pm 8,61, \quad 29,20 \pm 10,02, \quad$ dan $22,24 \pm 7,48$ $\mathrm{mgC} / \mathrm{m}^{3} / \mathrm{jam}$. Berdasarkan hasil sidik ragam nilai NPP antara stasiun menunjukkan perbedaan yang nyata pada taraf $\alpha 0,05$. Dari hasil uji lanjut Tukey (HSD) terlihat bahwa nilai NPP pada stasiun B menunjukkan nilai rata-rata NPP yang lebih besar yaitu $29,20 \pm 10,02 \mathrm{mgC} / \mathrm{m}^{3} / 4 \mathrm{jam}$ dan berbeda nyata dengan stasiun $\mathrm{A}$ dan $\mathrm{C}$, sedang stasiun A dan C menunjukan nilai rata-rata NPP berturut-turut sebesar 20,41 $\pm 8,61$ dan $22,24 \pm 7,48$ $\mathrm{mgC} / \mathrm{m}^{3} /$ jam serta tidak menunjukkan perbedaan yang nyata.

Distribusi vertikal nilai NPP pada kedalaman inkubasi diperoleh nilai tertinggi pada kedalaman inkubasi 50\% intensitas cahaya pada semua stasiun. Pada stasiun A nilai NPP berkisar 26,17-35,94 $\mathrm{mgC} / \mathrm{m}^{3} / 4 \mathrm{jam}$, stasiun B berkisar $35,16-44,53 \mathrm{mgC} / \mathrm{m}^{3} / 4$ jam dan stasiun $\mathrm{C}$ berkisar 23,83-36,77 $\mathrm{mgC} / \mathrm{m}^{3} / 4$ jam (Gambar 2). Berdasarkan hasil sidik ragam antara kedalaman inkubasi pada masing-masing stasiun menunjukkan perbedaan yang nyata pada taraf $\alpha$ 0,05 . Dari hasil uji Tukey (HSD) untuk stasiun A pada kedalaman inkubasi $50 \%$ menunjukkan nilai rata-rata NPP sebesar $31,64 \pm 4,20 \mathrm{mgC} / \mathrm{m}^{3} / 4 \mathrm{jam}$ dan berbeda nyata dengan kedalaman inkubasi $100 \%, 25 \%$, dan $1 \%$, sedang kedalaman inkubasi $100 \%, 25 \%$ dan $1 \%$ berturut-turut menunjukkan nilai rata-rata NPP sebesar $16,02 \pm 3,36$, $22,86 \pm 4,87$, dan $11,13 \pm 1,03 \mathrm{mgC} / \mathrm{m}^{3} / 4 \mathrm{jam}$, dimana kedalaman inkubasi $1 \%$ berbeda nyata dengan kedalaman $100 \%$ dan $25 \%$. Untuk kedalaman inkubasi $100 \%$ dan 25 tidak menunjukkan perbedaan yang tidak nyata. 

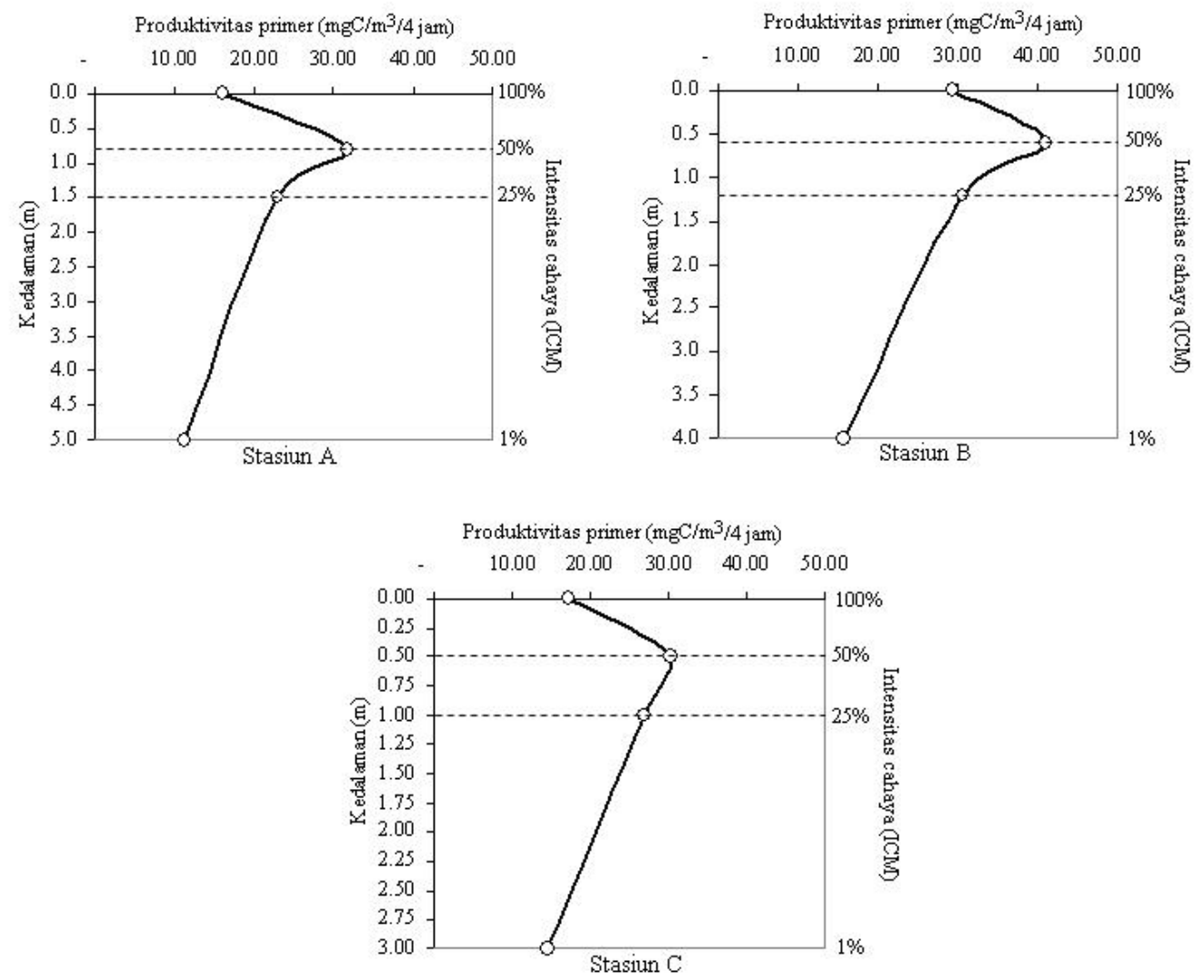

Gambar 2. Sebaran NPP pada masing-masing stasiun dan substasiun pada setiap kedalaman intensitas cahaya

Untuk stasiun B dari hasil uji lanjut nilai NPP antara kedalaman inkubasi menunjukkan perbedaan yang nyata. Pada kedalaman inkubasi $100 \%$ dan $25 \%$ menunjukkan nilai rata-rata NPP sebesar 29,34 $\pm 6,44 \mathrm{mgC} / \mathrm{m}^{3} / 4$ jam dan $30,67 \pm 2,68 \mathrm{mgC} / \mathrm{m}^{3} / 4$ jam dan tidak menunjukkan perbedaan yang nyata, tetapi berbeda nyata dengan kedalaman inkubasi $50 \%$ dan $1 \%$, dengan nilai rata-rata NPP berturut-turut sebesar 40,92 $\pm 4,10$ dan $15,86 \pm 3,63 \mathrm{mgC} / \mathrm{m}^{3} / 4$ jam. Untuk kedalaman $1 \%$ terlihat perbedaan yang nyata dengan kedalaman lainnya begitu pula dengan kedalaman $50 \%$ menunjukkan perbedaan yang nyata dengan kedalaman lainnya. Untuk stasiun $\mathrm{C}$ dari hasil uji lanjut menunjukkan bahwa pada kedalaman inkubasi $50 \%$ dan $25 \%$ tidak berbeda nyata, dengan nilai rata-rata NPP berturut-turut sebesar $30,20 \pm 5,37$ dan $26,89 \pm 1,74$ $\mathrm{mgC} / \mathrm{m}^{3} / 4$ jam. Namun kedalaman inkubasi $50 \%$ dan $25 \%$ berbeda nyata dengan kedalaman inkubasi $100 \%$ dan $1 \%$, dengan nilai rata-rata NPP sebesar 17,20 $\pm 4,43$ dan 14,66 $\pm 2,22$ $\mathrm{mgC} / \mathrm{m}^{3} / 4 \mathrm{jam}$.

\section{Unsur Hara}

Gabungan konsentrasi nitrat, nitrit dan ammonium atau yang disingkat (DIN) selama penelitian memperlihatkan nilai yang bervariasi. Rata-rata total DIN pada stasiun A berkisar 0,54$0,56 \mathrm{mg} / \mathrm{L}$, stasiun B berkisar $0,68-0,70 \mathrm{mg} / \mathrm{L}$, dan stasiun $\mathrm{C}$ berkisar 0,75-0,83 $\mathrm{mg} / \mathrm{L}$. Konsentrasi tertinggi dijumpai pada stasiun $\mathrm{C}$ dan mengalami penurunan ke arah laut (stasiun $\mathrm{A}$ dan B).

Konsentrasi amonia selama penelitian pada stasiun A mempunyai kisaran 0,02-0,09 $\mathrm{mg} / \mathrm{L}$, stasiun B berkisar antara 0,03-0,07 mg/L, dan stasiun $C$ berkisar antara 0,03-0,07 mg/L . Pola distribusi vertikal amonia pada setiap stasiun dan substasiun selama penelitian berdasarkan analisis ANOVA memperlihatkan tidak adanya perbedaan yang nyata pada taraf $\alpha$ 0,05 . distribusi vertikal amonium lebih seragam bila dibandingkan dengan unsur nitrogen lainnya (Dawes 1981; Mallin1994.).

Konsentrasi nitrat yang diperoleh selama penelitian berkisar antara 0,29-0,68 $\mathrm{mg} / \mathrm{L}$ pada 
stasiun A, 0,48-0,77mg/L pada stasiun $\mathrm{B}$, dan 0,55-1,07 $\mathrm{mg} / \mathrm{L}$ pada stasiun C. Konsentrasi nitrat cenderung memperlihatkan nilai yang semakin rendah ke arah laut (mulut teluk). Hal ini sejalan dengan hasil analisis sidik ragam (ANOVA) yang menunjukkan perbedaan yang nyata pada taraf $\alpha 0,05$. Dari hasil uji lanjut Tukey (HSD) terlihat bahwa konsentrasi nitrat pada stasiun $\mathrm{A}$ dan $\mathrm{C}$ menunjukkan perbedaan yang nyata, dengan rata-rata konsentrasi yang semakin rendah ke arah laut. Secara umum ketersediaan nitrat selama penelitian lebih rendah dari kebutuhan optimal fitoplankton untuk pertumbuhan yaitu 0,9-3,5 mg/l (Mackenthum (1969) diacu dalam Guilford dan Hecky 2000). Diduga pada saat pengukuran, konsentrasi nitrat yang terdapat di perairan telah dimanfaatkan oleh fitoplankton untuk pertumbuhannya. Hal ini sesuai dengan pernyataan Goes et al. (2004) bahwa konsentrasi nitrat yang mengalami penurunan sampai sekitar $6 \mathrm{M}$ atau setara dengan $0,456 \mathrm{mg} / \mathrm{L}$ menunjukkan telah terjadi penyerapan nitrat dengan cepat oleh fitoplankton. Konsentrasi nitrit yang dijumpai selama penelitian berkisar antara $0,01-0,05 \mathrm{mg} / \mathrm{L}$ pada stasiun $\mathrm{A}, 0,01-0,04 \mathrm{mg} / \mathrm{L}$ pada stasiun $\mathrm{B}$, dan pada stasiun $\mathrm{C}$ berkisar 0,01-0,04 mg/L. Konsentrasi nitrit yang diperoleh selama penelitian relatif lebih rendah dibandingkan unsur $\mathrm{N}$ lainnya.

Kisaran konsentrasi ortofosfat yang diperoleh selama penelitian pada stasiun A berkisar antara $0,02-0,11 \mathrm{mg} / \mathrm{L}$, pada stasiun B berkisar antara 0,06-0,13 mg/L, dan stasiun C antara $0,09-0,15 \mathrm{mg} / \mathrm{L}$. Menurut Millero dan Sohn (1992) pertumbuhan semua jenis fitoplankton tergantung pada konsentrasi ortofosfat. Bila konsentrasinya di bawah $0,3 \mu \mathrm{M}$ atau $0,038 \mathrm{mg} / \mathrm{L}$, maka perkembangan sel menjadi terhambat. Konsentrasi ortofosfat yang diperoleh selama penelitian masih berada dalam kisaran konsentrasi ortofosfat yang dibutuhkan untuk pertumbuhan optimal fitoplankton. Konsentrasi ortofosfat yng optimal untuk pertumbuhan fitoplankton berkisar antara 0,27$5,51 \mathrm{mg} / \mathrm{l}$ (Bruno et al. 1979 diacu dalam Widjaja et al. 1994) atau sekitar $0,09-1,80$ ppm (Mackentum 1969 diacu dalam Guilford dan Hecky 2000).

Konsentrasi silikat yang diperoleh selama penelitian di perairan Teluk Kendari adalah pada stasiun A berkisar antara 0,11-0,56 $\mathrm{mg} / \mathrm{l}$, pada stasiun B berkisar antara 0,48-0,78 $\mathrm{mg} / \mathrm{L}$, dan 0,28-0,77 mg/L pada stasiun C. Konsentrasi silikat yang dijumpai selama penelitian menunjukkan adanya kecenderungan penurunan konsentrasi silikat ke arah laut. Hal ini sejalan dengan hasil penelitian Damar (2003) bahwa pada stasiun mulut sungai, konsentrasi silikat lebih tinggi jika dibandingkan dengan stasiun yang berada di dalam perairan teluk.

\section{Intensitas Cahaya Matahari}

Besarnya nilai intensitas cahaya matahari yang mencapai permukaan laut berbeda-beda dari waktu ke waktu. Fenomena tersebut terjadi pula di perairan Teluk Kendari, yaitu bahwa intensitas cahaya matahari mencapai bagian atas permukaan air selama penelitian bervariasi (Gambar 3).

Besarnya intensitas cahaya matahari yang sampai bagian atas permukaan air mengikuti pola harian, yaitu mengalami peningkatan di pagi hari, mencapai puncak pada siang hari, selanjutnya menurun pada sore hari (Gambar 3). Nilai intensitas cahaya yang bervariasi selama penelitian ini, selain disebabkan oleh kondisi awan yang mempengaruhi intensitas cahaya yang sampai ke permukaan, juga dipengaruhi oleh perbedaan lokasi di bumi (letak lintang daerah yang diamati) (Parson et al. 1984).

Intensitas cahaya yang sampai di lapisan permukaan perairan pada lokasi penelitian bervariasi dari waktu ke waktu seperti halnya intensitas cahaya permukaan (Gambar 3). Berdasarkan Gambar 3, besarnya intensitas cahaya di bagian atas permukaan air akan mempengaruhi nilai intensitas cahaya pada lapisan permukaan perairan. Nilai intensitas cahaya mengalami peningkatan pada pagi hari dan mencapai puncak pada siang hari, serta mengalami penurunan pada sore harinya.

Distribusi cahaya matahari di kolom air akan mengalami peredupan. Nilai koefisien peredupan yang diperoleh selama penelitian, pada stasiun A berkisar 0,80-1,11 per meter, stasiun B berkisar 1,05-1,37 per meter, dan stasiun C berkisar 1,26-2,00 per meter. Nilai koefisien peredupan mengalami peningkatan ke arah bagian dalam teluk (stasiun C). Koefisien peredupan ini disebabkan oleh bahan-bahan yang ada dalam perairan baik oleh partikel tersuspensi, plankton maupun bahan organik. Kondisi tersebut sejalan dengan pernyataan Wyatt dan Jackson (1989) bahwa distribusi cahaya di kolom perairan tergantung pada kandungan dan 
kelompok partikel tersuspensi, seperti tipe partikel termasuk ukuran dan bentuk dari partikel tersebut. Peredupan cahaya di kolom air juga disebabkan oleh fitoplankton, partikel-partikel lain, bahan organik terlarut dan perairan itu sendiri (Kirk 1994). Pada perairan pesisir yang dangkal, bahan resuspensi akan memberikan konstribusi yang signifikan terhadap peredupan cahaya khususnya pada kondisi angin yang kencang (Campbell dan Spinrad 1987 diacu dalam Nielsen et al. 2002).

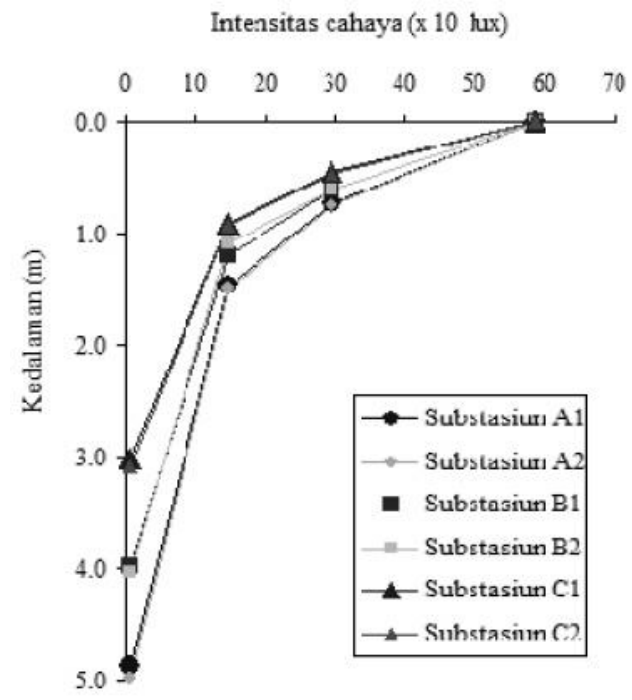

Gambar 4. Pola distribusi cahaya pada kolom perairan pada setiap stasiun/substasiun

Kedalaman zona fotik selama pengukuran adalah sekitar 4,15-5,78 $\mathrm{m}$ atau $33,16-52,54 \%$ dari kedalaman perairan pada stasiun A, 3,37-4,38 $\mathrm{m}$ atau $28,05-43,71 \%$ dari kedalaman perairan pada stasiun B, dan 2,30-3,66 $m$ atau $41,78-73,27 \%$ dari kedalaman perairan pada stasiun C. Pendugaan nilai dan persentase intensitas cahaya yang masuk ke kolom perairan berdasarkan hukum Lambert memperlihatkan pola distribusi cahaya di perairan, yaitu bahwa semakin dalam cahaya menembus lapisan air, semakin berkurang nilai intensitasnya (Gambar 4).

\section{Parameter Penunjang}

Sebagai perairan estuari, perairan Teluk Kendari masih dipengaruhi oleh pergerakan pasang surut air laut. Berdasarkan data Dishidros (2000) diacu dalam BAPPEDA Sultra dan PKSPL Badan Perencanaan Pembangunan Daerah Sulawesi Tenggara dan Pusat Kajian Sumberdaya Pesisir dan Lautan (2000) tipe pasang surut Teluk Kendari termasuk dalam kategori campuran mengarah ke semidiurnal. Hal ini menunjukkan bahwa di perairan Teluk Kendari terjadi kondisi pasang dan surut dua kali sehari dengan ketinggian pasang yang berbeda. Tinggi pasang dan surut pertama adalah 1,1 meter dan kisaran pasang dan surut kedua adalah 0,4-0,7 meter.

Kecepatan arus selama penelitian berkisar antara 0,40-0,81 m/dtk. Kecepatan arus yang tinggi dijumpai pada stasiun A yang berhadapan dengan laut (luar teluk), dan mengalami penurunan ke arah dalam teluk. Suhu perairan selama penelitian di perairan Teluk Kendari di seluruh kedalaman inkubasi pada stasiun dan substasiun penelitian berkisar 28,5$30,6^{\circ} \mathrm{C}$. Salinitas yang diperoleh selama penelitian berkisar antara $19,80-29,80 \%$ o. Nilai salinitas terendah dijumpai pada stasiun $\mathrm{C}$ (substasiun $\mathrm{C} 1$ dan $\mathrm{C} 2$ ). Berdasarkan hasil pengukuran $\mathrm{pH}$ selama penelitian di perairan Teluk Kendari berkisar antara 7,20-7,70.

Nilai kekeruhan dan TSS selama penelitian berkisar antara 3,09-10,19 NTU dan $282-392 \mathrm{mg} / \mathrm{l}$. Nilai kekeruhan dan TSS tertinggi dijumpai pada stasiun C. Nilai kecerahan selama penelitian berkisar 0,69-2,05 m. Nilai kecerahan tertinggi terdapat pada stasiun A (mulut teluk). Umumnya nilai parameter penunjang yang dijumpai selama penelitian merupakan kisaran 
yang mendukung pertumbuhan fitoplankton di perairan.

\section{PEMBAHASAN}

\section{Hubungan Produktivitas Primer dengan Intensitas Cahaya}

Hubungan produktivitas primer dengan cahaya dianalisis menggunakan regresi kuadratik. Dari hasil analisis terbentuk keeratan hubungan
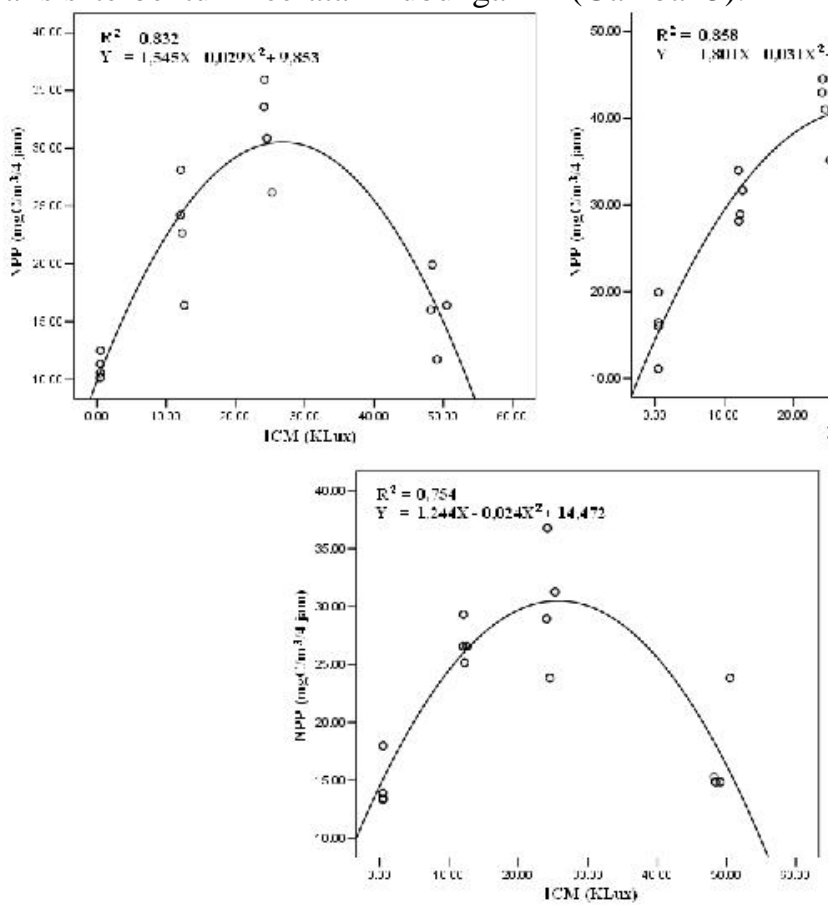

Gambar 5. Hubungan NPP dengan intensitas cahaya

Kisaran intensitas cahaya optimum bagi produktivitas primer dapat diduga melalui pola hubungan NPP dengan intensitas cahaya berdasarkan persamaan di atas yaitu pada stasiun A intensitas cahaya optimum berkisar 25,6627,24 Klux dengan nilai NPP berkisar 30,40$30,63 \mathrm{mgC} / \mathrm{m}^{3} / 4$ jam, pada stasiun $\mathrm{B}$ intensitas cahaya berkisar 27,78-30,12 Klux dengan nilai NPP berkisar 40,57-40,62 $\mathrm{mgC} / \mathrm{m}^{3} / 4$ jam, dan pada stasiun $\mathrm{C}$ berkisar 24,91-26,83 Klux dengan nilai NPP berkisar 30,57-30,59 $\mathrm{mgC} / \mathrm{m}^{3} / 4 \mathrm{jam}$.

Berdasarkan persamaan hubungan NPP dengan intensitas cahaya, maka dapat dihitung nilai produktivitas primer untuk setiap lapisan kolom air pada masing-masing stasiun. Pola hubungan yang terbentuk antara NPP dengan intensitas cahaya membentuk pola hubungan yang kuadratik (Gambar 6), dimana setiap yang tinggi antara NPP dengan intensitas cahaya pada semua stasiun. Hal ini terlihat dari nilai koefisien determinasi $\left(\mathrm{R}^{2}\right)$ yaitu pada stasiun $A$ sebesar 0,832 dengan persamaan $\mathrm{Y}=1,545 \mathrm{X}-$ $0,029 X^{2}+9,853$, stasiun B sebesar 0,858 dengan persamaan $\mathrm{Y}=1,801 \mathrm{X}-0,031 \mathrm{X}^{2}+14,462$, dan stasiun $\mathrm{C}$ sebesar 0,754 dengan persamaan $\mathrm{Y}=$ $1,244 \mathrm{X}-0,024 \mathrm{X}^{2}+14,472$ pada taraf $\alpha 0,05$ (Gambar 5).

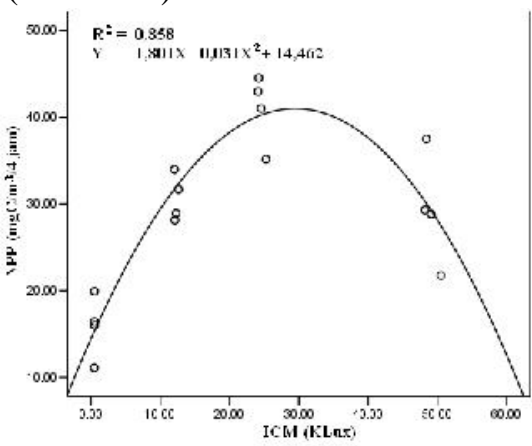

peningkatan intensitas cahaya matahari akan selalu diikuti dengan peningkatan nilai NPP sampai pada suatu titik optimum. Di atas intensitas cahaya optimum merupakan cahaya penghambat sedangkan di bawah intensitas cahaya optimum merupakan cahaya pembatas (Kirk 1994).

Nilai maksimum NPP yang diperoleh berdasarkan persamaan hubungan NPP dengan intensitas cahaya pada masing-masing stasiun dengan kedalaman perairan yang tidak terlalu bervariasi. Pada stasiun A nilai maksimum NPP yang diperoleh yaitu $29,67 \mathrm{mgC} / \mathrm{m} 3 / 4$ jam pada kedalaman 0,7 meter, pada stasiun $\mathrm{B}$ diperoleh nilai NPP maksimum yaitu $39,65 \mathrm{mgC} / \mathrm{m} 3 / 4$ jam pada kedalaman 0,6 meter dan stasiun $\mathrm{C}$ nilai NPP maksimum yaitu $29,79 \mathrm{mgC} / \mathrm{m} 3 / 4$ jam pada kedalaman 0,5 meter (Gambar 6). 

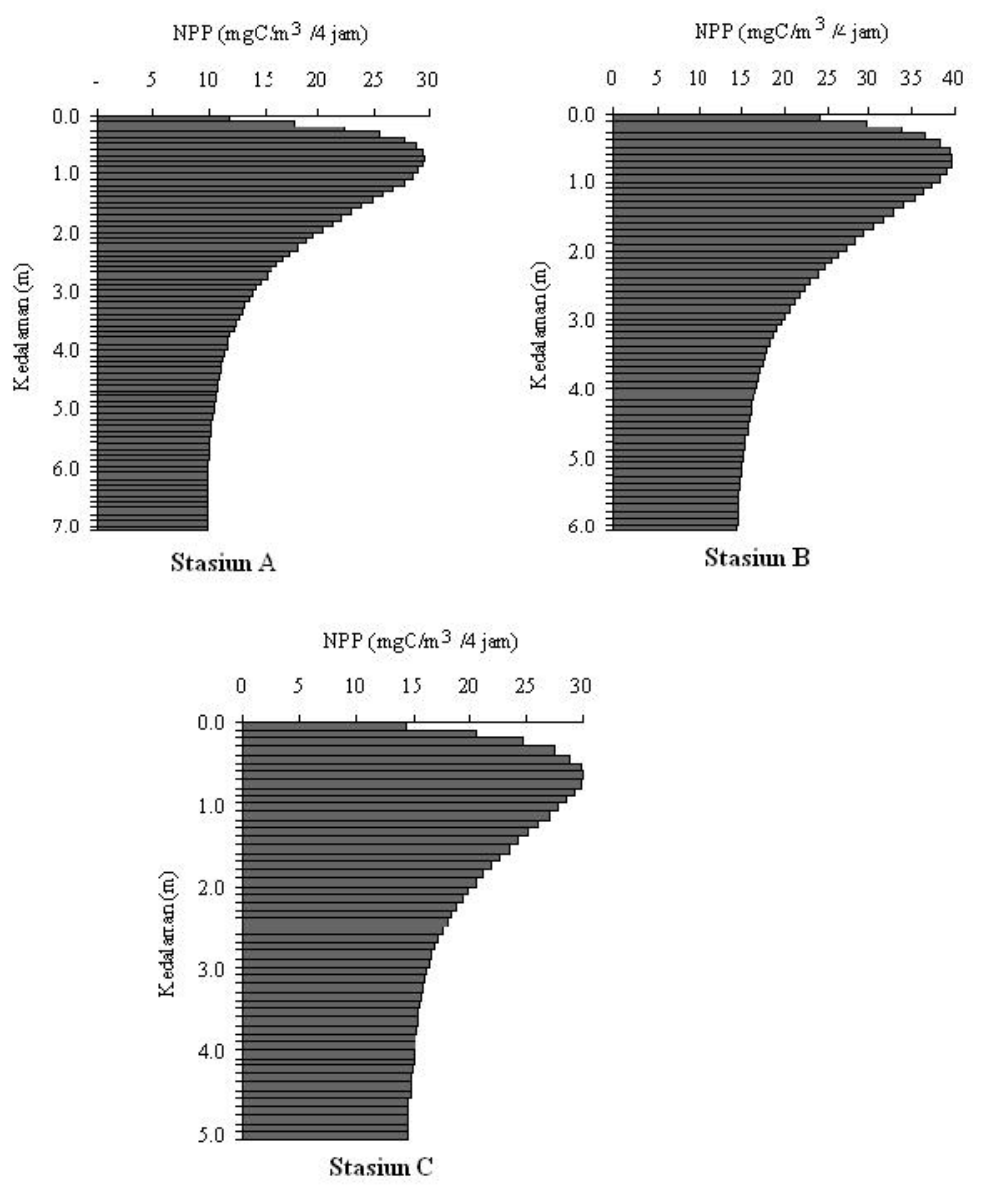

Gambar 6. Grafik hubungan produktivitas primer (NPP) dengan kedalaman perairan

\section{Hubungan Produktivitas Primer dengan Unsur hara dan intensitas cahaya}

Berdasarkan hasil analisis regresi berganda hubungan antara produktivitas primer dengan unsur hara (amonia, nitrat, nitrit, ortofosfat dan silikat) serta intensitas cahaya (ICM) menunjukkan korelasi yang beragam pada masing-masing stasiun. Pada stasiun A diperoleh keeratan hubungan yang tinggi dengan nilai $\mathrm{R}^{2}$ sebesar 0,920 , persamaan yang terbentuk yaitu $\mathrm{Y}$ $=0,181 \mathrm{ICM}^{*}-0,635$ amonia* $^{*} 0,717$ nitrat* + 0,277 nitrit $+1,096$ ortofosfat $-0,605$ silikat + 1,412 (Tabel 1). Dari persamaan tersebut menunjukkan bahwa unsur hara amonia dan silikat memberikan hubungan negatif terhadap produktivitas primer di stasiun $\mathrm{A}$, sedang unsur hara nitrat, nitrit, dan ortofosfat serta ICM memberikan hubungan yang positif terhadap nilai NPP, sehingga penurunan unsur hara amonia dan silikat serta peningkatan unsur hara nitrat, nitrit, dan ortofosfat serta ICM akan memberikan peningkatan terhadap nilai NPP. Berdasarkan uji $\mathrm{t}$ dan nilai signifikan pada masing-masing unsur hara dan ICM, unsur hara amonia, nitrat, nitrit, dan ICM secara nyata memberikan pengaruh terhadap nilai NPP tinggi dan rendahnya di stasiun A.

Pada stasiun B diperoleh keeratan hubungan yang tinggi dengan nilai $\mathrm{R}^{2}$ sebesar 0,878 , persamaan yang terbentuk yaitu $\mathrm{Y}=0,138$ ICM $^{*}-0,322$ amonia $+0,570$ nitrat* $+0,018$ nitrit $+0,134$ ortofosfat $-0,854$ silikat $+0,673$ (Tabel 1). Berdasarkan persamaan tersebut menunjukkan bahwa kelima unsur hara dan ICM memberikan pengaruh yang besar terhadap nilai NPP di stasiun B. Unsur hara amonia dan silikat memberikan hubungan negatif, sedang unsur hara nitrit, ortofosfat dan silikat serta ICM memberikan hubungan positif terhadap nilai NPP. Sehingga penurunan unsur hara amonia dan silikat serta peningkatan unsur hara nitrit, ortofosfat dan silikat serta ICM akan memberikan peningkatan terhadap nilai NPP. Berdasarkan uji $\mathrm{t}$ dan nilai signifikan pada masing-masing unsur hara dan ICM, unsur hara nitrat dan ICM secara 
nyata memberikan pengaruh terhadap nilai NPP di stasiun B.

Pada stasiun C diperoleh keeratan hubungan yang tinggi dengan nilai $\mathrm{R}^{2}$ sebesar 0,798 persamaan yang terbentuk yaitu $\mathrm{Y}=0,144$ $\mathrm{ICM}^{*}+0,251$ amonia $+0,797$ nitrat $+0,209$ nitrit $+0,347$ ortofosfat $+0,818$ silikat $+2,156$ (Tabel 1). Berdasarkan persamaan tersebut kelima unsur hara dan ICM memberikan

Tabel 1. Model regresi dan koefisien determinasi serta parameter yang berpengaruh nyata berdasarkan hasil regresi produktivitas primer fitoplankton dengan unsur hara dan intensitas cahaya

\begin{tabular}{|c|c|c|c|c|c|}
\hline Stasiun & Model regresi & $\begin{array}{l}\text { Sig. } \\
\text { Model }\end{array}$ & $\mathbf{R}^{2}$ & $\begin{array}{c}\text { Parameter } \\
\text { nyata }\end{array}$ & $\begin{array}{c}\text { Sig. } \\
\text { parameter }\end{array}$ \\
\hline \multirow[t]{3}{*}{ A } & \multirow{3}{*}{$\begin{array}{l}Y=0,181 \mathrm{ICM}^{*}-0,635 \text { amonia* }+ \\
0,717 \text { nitrat* }+0,277 \text { nitrit }+1,096 \\
\text { ortofosfat }-0,605 \text { silikat }+1,412\end{array}$} & \multirow[t]{3}{*}{0,000} & \multirow[t]{3}{*}{0,920} & ICM & 0,000 \\
\hline & & & & Amonia & 0,038 \\
\hline & & & & Nitrat & 0,001 \\
\hline \multirow[t]{2}{*}{ B } & \multirow{2}{*}{$\begin{array}{l}\mathrm{Y}=0,138 \mathrm{ICM}^{*}-0,322 \text { amonia }+ \\
0,570 \text { nitrat* }+0,018 \text { nitrit }+0,134 \\
\text { ortofosfat }-0,854 \text { silikat }+0,673\end{array}$} & \multirow[t]{2}{*}{0,001} & \multirow[t]{2}{*}{0,878} & ICM & 0,017 \\
\hline & & & & Nitrat & 0,008 \\
\hline \multirow[t]{2}{*}{$\mathrm{C}$} & \multirow{2}{*}{$\begin{array}{l}\mathrm{Y}=0,144 \mathrm{ICM}^{*}+0,251 \text { amonia }+ \\
0,797 \text { nitrat* }+0,209 \text { nitrit }+0,347 \\
\text { ortofosfat }+0,818 \text { silikat }+2,156\end{array}$} & \multirow[t]{2}{*}{0,009} & \multirow[t]{2}{*}{0,798} & ICM & 0,004 \\
\hline & & & & Nitrat & 0,004 \\
\hline
\end{tabular}

Ket: * : Parameter nyata

Berdasarkan uji regresi berganda antara hubungan NPP dengan unsur hara dan ICM, menunjukkan pola yang hampir sama antara ketiga stasiun penelitian. Pada stasiun A ketiga unsur hara $\mathrm{N}$ (amonia, nitrat, dan nitrit) dan intensitas cahaya menjadi faktor yang memberikan pengaruh nyata terhadap tinggi dan rendahnya nilai NPP, sedang pada stasiun B dan $\mathrm{C}$, unsur hara nitrat bersama ICM memberikan pengaruh yang nyata terhadap tinggi dan rendahnya nilai NPP di perairan. Hal ini disebabkan keberadaan unsur hara amonia di perairan biasanya digunakan secara langsung oleh fitoplankton untuk mensintesa asam-asam amino melalui proses transminasi (Mann 1982), selain itu fitoplankton lebih banyak menyerap amonia ketimbang nitrat yang lebih banyak dijumpai di perairan baik dalam kondisi aerobik maupun anaerobik (Welch 1980).

Intensitas cahaya menjadi faktor yang dominan memberikan pengaruh terhadap nilai NPP di semua stasiun penelitian. Hal ini sejalan dengan penelitian Tambaru (2008) di perairan pesisir Maros, bahwa parameter intensitas cahaya merupakan parameter dominan mempengaruhi nilai NPP selain keberadaan unsur hara. Hal ini diduga keberadaan parameter intensitas cahaya merupakan faktor pembatas pada perairan pesisir hubungan positif terhadap nilai NPP, sehingga peningkatan nilai unsur hara dan ICM akan memberikan peningkatan terhadap nilai NPP pada stasiun C. Namun berdasarkan uji t dan nilai signifikan pada masing-masing unsur hara dan ICM, unsur hara nitrat dan ICM yang secara nyata memberikan pengaruh terhadap tinggi dan rendahnya nilai NPP di stasiun C. Seperti yang dinyatakan oleh Fisher et al. (1999), Yoshiyama dan Sharp (2006) bahwa cahaya dapat menjadi pembatas bagi pertumbuhan fitoplankton dan biomassa fitoplankton. Cahaya sebagai pembatas hadir ketika konsentrasi unsur hara dan kekeruhan tinggi dan kedalaman tercampur (mixing depth) lebih besar tiga sampai lima kali kedalaman eufotik. Sejalan dengan Malone dan Neale (2004) dan Al-Yamani et al. (2006), pada kawasan estuari yang memiliki turbiditas yang tinggi, maka faktor pembatas dari produksi fitoplankton adalah cahaya bukan nutrien.

\section{KESIMPULAN}

Nilai produktivitas primer selama penelitian pada perairan Teluk Kendari yaitu pada stasiun luar teluk berkisar 16,99 - 26,37 $\mathrm{mgC} / \mathrm{m}^{3} / \mathrm{jam}$, pada stasiun tengah teluk 21,09 $31,25 \mathrm{mgC} / \mathrm{m}^{3} / \mathrm{jam}$, dan $11,13-24,61 \mathrm{mg}$ $\mathrm{C} / \mathrm{m}^{3} / \mathrm{jam}$ pada stasiun dalam teluk. Hubungan produktivitas primer dan ICM memperlihatkan keeratan yang kuat pada ketiga stasiun penelitian, sedang produktivitas primer dengan unsur hara dan ICM menunjukkan pola yang hampir sama pada ketiga stasiun penelitian. Pada stasiun luar teluk, unsur hara amonia dan nitrat bersama ICM yang disebabkan oleh kekeruhan yang tinggi. 
menjadi faktor yang memberikan pengaruh nyata terhadap tinggi rendahnya nilai NPP, sedang pada stasiun tengah dan dalam teluk, unsur hara nitrat dan ICM memberikan pengaruh yang nyata terhadap tinggi dan rendahnya nilai NPP di perairan Teluk Kendari.

\section{DAFTAR PUSTAKA}

Alianto. 2006. Produktifitas primer fitoplankton dan keterkaitannya dengan unsur hara dan cahaya di Perairan Teluk Banten. Tesis (Tidak Dipublikasikan). Sekolah Pascasarjana. Institut Pertanian Bogor.

BAPPEDA Sultra dan PKSPL Badan Perencanaan Pembangunan Daerah Sulawesi Tenggara dan Pusat Kajian Sumberdaya Pesisir dan Lautan. 2000. Atlas Sumberdaya Pesisir dan Laut Teluk Kendari dan Sekitarnya. Kerjasama BAPPEDA Propinsi Sulawesi Tenggara dengan PKSPL Institut Pertanian Bogor. Bogor.

Cole, G.A. 1988. Textbook of Limnology. Ed. Ke-3. Illionis : Waveland Press, Inc.

Damar, A. 2003. Effects of Enrichment on Nutrient Dynamics, Phytoplankton Dynamics and Productivity in Indonesian Tropical Water: A Comparison Between Jakarta Bay, Lampung Bay and Semangka Bay. Ph.D Dissertation Christian Albrechts University. Kiel. Germany.

Dawes, J.C. 1981. Marine botany. A Wiley Interscience Publication, University of South Florida.

Fisher, T.R., Gustafson, A.B., Sellner, K., Lacouture, R., Haas, L.W., Wetzel, R.L., Magnien, R., Everitt, D., Michaels, B. dan Karrh, R. 1999. Spatial and temporal variation of resource limitation in Chesapeake Bay. Marine Biology. 133: 763-778.

Goes, J.I., Sasaoka, K., Helgado, R., Gomes, H.D.R., Sei0Ichi, S. dam Toshiro, S. 2004. A comparison of the seasonality and interannual variability of phytoplankton biomass and production in the Western and Eastern Gyres of the Subarctic Pacific using multi-sensor satellite data. Journal of Oceanography, 60: 75 -91.]
Guilford, S.J. dan Hecky, R.E. 2000. Total nitrogen, total phosphorus and nutrient limitation in lakes and oceans: is there a common relationship. Limnology and Oceanography. 45: 1213-1223.

Kirk, J.T.O. 1994. Light and Photosynthesis in Aquatic Ecosystems. Cambridge University Press. Cambridge.

Mallin, M.A.1994. Phytoplankton ecology of North Carolina Estuaries. Estuaries. 17: 561-574.

Malone T.C \& P. J. Neale. 2004. Parameters of Light-Dependent Photosynthesis for Phytoplankton Size Fractions in Temperate Estuarine. Marine Biology, Lamont-Doherty Geological Observatory; Palisades. New York. USA. Marine Biology 61: 289-297

Mattjik, A.A. dan M. Sumertajaya. 2000. Perancangan Percobaan Dengan Aplikasi SAS dan MINITAB. Jilid I. IPB Press. Bogor.

Millero, F.J. dan M.L.Sohn. 1992. Chemical Oceanography. CRC Press. Boca Raton Ann Arbor. London.

Nielsen, S.L., Sand-Jensen, K., Borum, J. dan Hansen, O.G. 2002. Phytoplankton, nutrient and transparency in Danish coastal water. Estuaries 25: 930-937.

Oviatt, C., A. Keller dan L. Reed. 2002. Annual primary production in Narragansett Bay with no Bay-Wide winter-spring phytoplankton bloom. Estuarine, Coastal and Shelf Science. 54: 1013-1026.

Parson, T.R., M. Takahashi dan B. Hargrave. 1984. Biological Oceanographic Processes. Third Edition. Pergamon Press. Oxford.

Tambaru, R. 2008. Dinamika komunitas fitoplankton dalam kaitannya dengan produktivitas perairan di perairan pesisir Maros Sulawesi Selatan. Tesis (Tidak Dipublikasikan). Sekolah Pascasarjana. Institut Pertanian Bogor.

Tillman, U., K.J. Hesse dan F. Colijn. 2000. Planctonic Primary Production in The German Wadden Sea. Journal Plankton Research. 22(7) : 1253-1276.

Welch, E.B. 1980. Ecological effects wastewater. Cambridge Press. London. Philadelphia.

Widjaja, F., Suwignyo, S., Yulianda, F. dan Effendie, H. 1994. Komposisi jenis, kelimpahan dan penyebaran plankton laut 
di Teluk Pelabuhan Ratu Jawa Barat. Laporan Penelitian, Fakultas Perikanan, Institut Pertanian Bogor.

Wyatt, P.J. dan Jackson, C. 1989. Discrimination of Phytoplankton Via Light-Scattering Properties. Limnology and Oceanography. 34: 96-112.

Al-Yamani, F., D.V. Subba Rao, A. Mharzi, W. Ismail dan K. Al-Rifaie. 2006. Primary production off Kuwait, an arid zone environment, Arabian Gulf. International
Journal of Ocean and Oceanography. Vol.1 No.1: 67-85.

Yoshiyama, K. dan J.H. Sharp. 2006. Phytoplanktonresponse to nutrient enrichment in an urbanized estuary : Apparent inhibition of primery production by overeutrophication. Limnol. Oceanogr. 51(1, part 2): 424434. 